\title{
Synthesis and Enzymatic Evaluation of the Guanosine Analogue 2-Amino-6-mercapto- 7-methylpurine Ribonucleoside (MESG). Insights into the Phosphorolysis Reaction Mechanism based on the Blueprint Transition State: $S_{N} 1$ or $S_{N} 2$ ?
}

\author{
Brenno A. D. Neto, ${ }^{*, a}$ Alexandre A. M. Lapis, ${ }^{b}$ Paulo A. Netz, ${ }^{c}$ John Spencer, ${ }^{d}$ Silvio L. P. Dias, ${ }^{c}$ \\ Silvia M. Tamborim, ${ }^{c}$ Luiz A. Basso, ${ }^{e}$ Diógenes S. Santos ${ }^{e}$ and Jairton Dupont ${ }^{*, c}$ \\ ${ }^{a}$ Laboratory of Medicinal and Technological Chemistry, University of Brasilia (IQ-UnB), \\ 72919-970 Brasilia-DF, Brazil \\ ${ }^{b}$ Universidade Federal do Pampa, Unipampa, 96412-420 Bagé-RS, Brazil \\ ${ }^{c}$ Laboratory of Molecular Catalysis-Institute of Chemistry-UFRGS, Av. Bento Gonçalves, 9500, \\ 91501-970 Porto Alegre-RS, Brazil \\ ${ }^{d}$ School of Science, University of Greenwich at Medway, Chatham Maritime, ME4 4TB, UK \\ ${ }^{e}$ Centro de Pesquisas em Biologia Molecular e Funcional, Tecnopuc, PUC, 90610-001 Porto Alegre-RS, Brazil
}

\begin{abstract}
A modificação experimental para a síntese do MESG (2-amino-6-mercapto-7-metilpurina ribonucleosídeo) 1 foi realizada com sucesso e sua caracterização total apresentada. ESI(+)-MSMS em alta resolução foram realizados indicando que a clivagem nucleosídica como principal e um possível mecanismo $\mathrm{S}_{\mathrm{N}} 1$. Cálculos ab initio baseados em estados de transição blueprint corroboram com a proposta de um mecanismo $\mathrm{S}_{\mathrm{N}} 1$ e descartam a possibilidade de um mecanismo $\mathrm{S}_{\mathrm{N}} 2$. Ensaios com a enzima purina nucleosídica fosforilase (PNP, tanto humana como de M. tuberculosis) indicam a eficiência do substrato na reação de fosforilação do MESG e permitem a determinação de fosfato inorgânico em tempo real em ensaios biológicos.
\end{abstract}

A modified experimental procedure for the synthesis of MESG (2-amino-6-mercapto-7methylpurine ribonucleoside) $\mathbf{1}$ has been successfully performed and its full characterization is presented. High resolution ESI(+)-MSMS indicates both the nucleoside bond cleavage as the main fragmentation in the gas phase and a possible $\mathrm{S}_{\mathrm{N}} 1$ mechanism. Ab initio transition state calculations based on the blue print transition state support this mechanistic rationale and discard an alternative $\mathrm{S}_{\mathrm{N}} 2$ mechanism. Assays using purine nucleoside phosphorylase (PNP) enzyme (human and M. tuberculosis sources) indicate its efficiency in the phosphorolysis of MESG and allow the quantitative determination of inorganic phosphate in real time assay.

Keywords: MESG, PNP enzyme, ESI, tuberculosis

\section{Introduction}

2-Amino-6-mercapto-7-methylpurine ribonucleoside 1 (MESG) is a very important substrate for the continuous spectrophotometric assay of inorganic phosphate and for measuring phosphate release kinetics in biological systems. ${ }^{1}$ In addition, $\mathbf{1}$ has been employed in the discovery of purine nucleoside phosphorylase (PNP) enzyme inhibitors. ${ }^{2}$ It has been established that this molecule is an important substrate for PNP and the kinetics of its phosphorolysis (or hydrolysis) can be conveniently

\footnotetext{
*e-mail: brenno.ipi@gmail.com; jairton.dupont@ufrgs.br
}

followed spectrophotometrically in the range of 355-360 nm (Scheme 1). ${ }^{3}$ The PNP-catalyzed phosphorolysis of the guanosine analogue MESG $\left(\lambda_{\max }=330 \mathrm{~nm}\right.$ at $\mathrm{pH}$ 7.6) releases the free base 2-amino-6-mercapto-7-methylpurine $2\left(\lambda_{\max }=360 \mathrm{~nm}\right.$ at $\left.\mathrm{pH} 7.6\right) .1$ has also been used to monitor the activities of several ATPases. ${ }^{4}$

PNP is an enzyme of great importance and plays a role in clinical medicine, ${ }^{5}$ especially because this enzyme is associated with profound immunodeficiency in T-cell function. ${ }^{6,7}$ Further interest in this enzyme has significantly increased since the discovery that the congenital absence of its activity causes T-cell impairment in human beings, though keeping normal levels of B-cells. ${ }^{8}$ Human PNP 
is therefore a target for the development of drugs to treat immunological disorders, such as rheumatoid arthritis, psoriasis, inflammatory bowel disorders and multiple sclerosis, and T-cell proliferative disorders, such as organ transplant rejection, T-cell lymphoma and T-cell leukemia.

Hence, an efficient and appropriate methodology for synthesis and characterization of $\mathbf{1}$ is essential to our research interests in biological systems. ${ }^{9-13}$ A previously described synthesis of this compound is found in the literature ${ }^{14}$ although the old methodology employed has inherent technical problems. Furthermore, it is surprising that for this important substrate, its physical-chemical properties have hitherto not been described. Based on our interest in the study of PNP enzymes ${ }^{15}$ and in the chemistry of biologically active compounds, ${ }^{16-19}$ we describe herein an adapted synthesis and full spectroscopic characterization of $\mathbf{1}$. An insight into the phosphorolysis mechanism is also discussed based on electrospray ionization (tandem) mass spectrometry analysis.

\section{Experimental}

\section{General}

All chemicals were purchased from commercial sources. All calculations were carried out using Gaussian 98, with optimization using $a b$ initio RHF calculation with basis sets $3-21 \mathrm{G}$ and $6-31 \mathrm{G}^{* *}$. The transition state calculations, assuming an $\mathrm{S}_{\mathrm{N}} 2$ (first) and an $\mathrm{S}_{\mathrm{N}} 1$ (latter) mechanisms,<smiles>C[N+]([O-])(O)c1c(S)nc(N)nc1N1CC(O)C(CO)C(O)C1O</smiles>

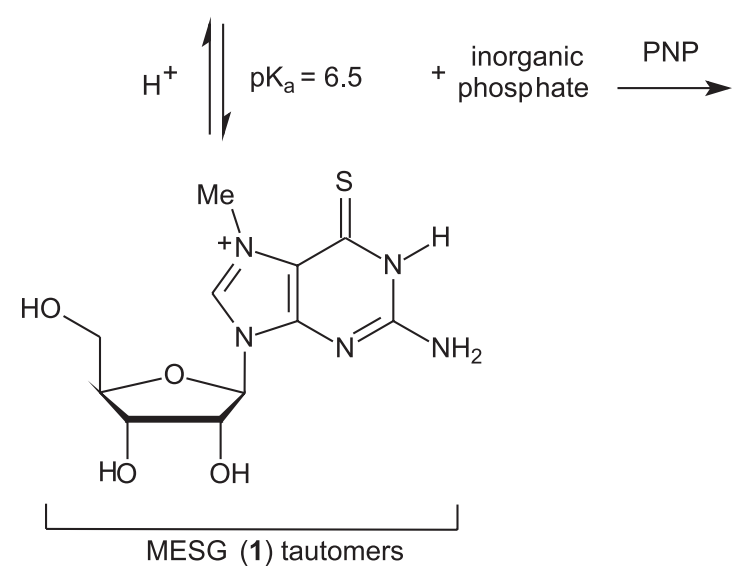

Scheme 1. Phosphorolysis of MESG 1 promoted by the PNP enzyme. were carried out with the same basis and using a QST2 optimization. Both MESG isomers (basic $\mathrm{pH}$ tautomer and acidic $\mathrm{pH}$ tautomer, see Scheme 1) were considered, as well as the corresponding free-base isomers. ESI mass and tandem mass spectra in positive ion modes were acquired using a Micromass (Manchester-UK) QTof instrument of ESI-QqTof configuration with 7.000 mass resolving power in the TOF mass analyzer. The following typical operating conditions were used: $3 \mathrm{kV}$ capillary voltage, $20 \mathrm{~V}$ cone voltage, and dessolvation gas temperature of $110^{\circ} \mathrm{C}$.

\section{General procedure to the synthesis of MESG 1}

In a Fischer-Porter reactor, under argon atmosphere, 2-amino-6-chloro-purine ribonucleoside $(4.00 \mathrm{~g}$, $13.25 \mathrm{mmol}$ ) was dissolved in dry dimethylformamide (10 mL). Methyl iodide (4 mL, (9.12 g), $64.25 \mathrm{mmol})$ was added and the mixture was stirred overnight $\left(\mathrm{T}=30^{\circ} \mathrm{C}\right)$. Excess methyl iodide was removed under high vacuum. Part of the DMF is also removed during this procedure, but it guarantees the total removal of methyl iodide. Thiourea (2.00 g, $26.27 \mathrm{mmol}$ ) was added under an argon atmosphere and the mixture was stirred for an additional hour. Afterwards, pure dimethylamine was slowly added dropwise until the solution became neutral (naked eye observation by color change). This can also be tested with $\mathrm{pH}$ indicator paper, but was not necessary. The mixture was directly poured into stirred acetone $(500 \mathrm{~mL})$ to give a yellow precipitate. The solid was collected by filtration<smiles>C[Y9]1cn([Tl])c2nc(N)[nH]c(=S)c12</smiles>

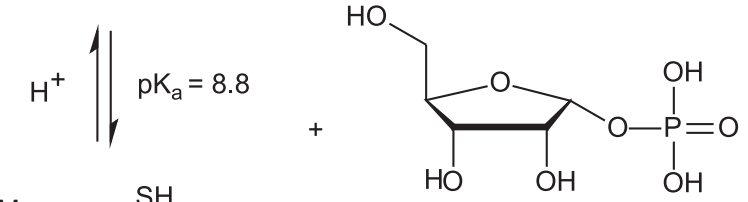<smiles>CN1CC[18O]C1S</smiles>

Free base (2) tautomers 
and dried in vacuum yielding compound $\mathbf{1}(4.73 \mathrm{~g}, 81 \%)$. Depending on the source of 2-amino-6-chloro-purine ribonucleoside, compound 1 was further chromatographed in silica eluted with ethyl acetate/1-propanol/water (5:2:1; $\mathrm{v} / \mathrm{v})$. The compound was dried to a yellow solid and stored desiccated at $-80{ }^{\circ} \mathrm{C}$. MESG can be stored at $-80{ }^{\circ} \mathrm{C}$ over a long period. Decomposition occurs at room temperature. Solutions (water or commonly used buffers) are more stable than pure 1. The elemental analysis must be collected immediately after purification. ${ }^{1} \mathrm{H}$ NMR analysis was as expected. ${ }^{13} \mathrm{C}$ NMR (APT) (DMSO-d $)$ : $\delta$ ppm 183.8, 162.4, 159.7, 146.3, 118.3, 88.3, 85.6, 74.0, 69.5, 60.6, 36.8. FTIR $\left(\mathrm{KBr}, v_{\max } / \mathrm{cm}^{-1}\right): 3338,1603,1540,1260,1041$. Elemental Anal. Calc. for $\mathrm{C}_{11} \mathrm{H}_{16} \mathrm{IN}_{5} \mathrm{O}_{4} \mathrm{~S}: \mathrm{C}, 29.94 ; \mathrm{H}, 3.65 ; \mathrm{N}, 15.87$. Found: C, 29.90; H, 3.55; N, 15.99 .

\section{Results and Discussion}

The modified synthesis of $\mathbf{1}$ (Scheme 2) was performed by addition of methyl iodide directly in a Fischer-Porter reactor, under an argon atmosphere, to 2-amino-6-chloropurine ribonucleoside, and stirred sealed overnight, affording the imidazolium intermediate. Untreated methyl iodide was removed under high vacuum. Thiourea was directly added in the reactor and the reaction mixture was stirred for an additional hour. The inconvenience of using "methanolic ammonia" from the original procedure ${ }^{14}$ can be avoided by direct dimethylamine addition dropwise until the solution became neutral. The acidity change is evident by color change (from yellow to light yellow) and was corroborated with $\mathrm{pH}$ indicator paper. Freshly formed compound $\mathbf{1}$ was then purified and stored at $-80^{\circ} \mathrm{C}$.
The electrochemical behaviour of $\mathbf{1}$ was investigated by cyclic voltammetry. The cyclic voltammogram (CV) of $\mathbf{1}$ is presented in Figure 1.

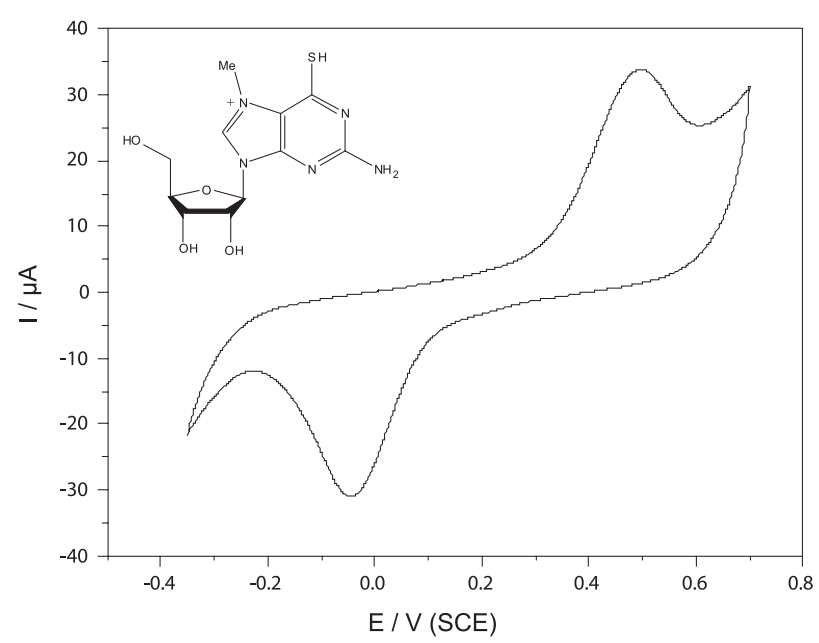

Figure 1. Cyclic voltammogram of compound $\mathbf{1}\left(1 \mathrm{mmol} \mathrm{L}^{-1}\right.$ solution) in a $100 \mathrm{mmol} \mathrm{L}^{-1}$ solution of $\mathrm{KCl}(20 \mathrm{~mL}$ at $\mathrm{pH} 7.2)$ recorded at a scan rate of $20 \mathrm{mV} \mathrm{s}^{-1}$.

Non-symmetric redox couples for well defined cathodic and anodic peaks are observed at -0.044 and $496 \mathrm{mV}$ (vs. SCE), respectively. As the structure suggests, the reduction of $\mathbf{1}$ is facile mainly because of the presence of an iminiumtype nitrogen. The peak separation value observed during the charge transfer process $(\Delta \mathrm{Ep})$ is $540 \mathrm{mV}$. The large difference observed in both charge transfer processes suggests a slow process at the surface of the platinum electrode. The current ratio of the anodic and cathodic peaks $\left(\mathrm{I}_{\mathrm{pa}} / \mathrm{I}_{\mathrm{pc}}\right)$ is slightly smaller than unity $(0.7)$, signifying that the electrochemical process is quasi-reversible.<smiles>Nc1nc(Cl)c2ncn(C3OC(CO)C(O)C(O)C3O)c2n1</smiles>

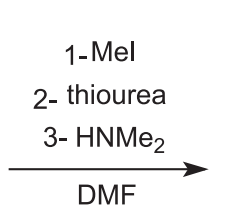

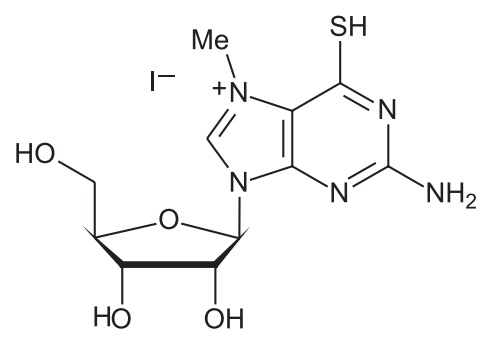<smiles>COC(O)C(O)C(O)CO</smiles> 


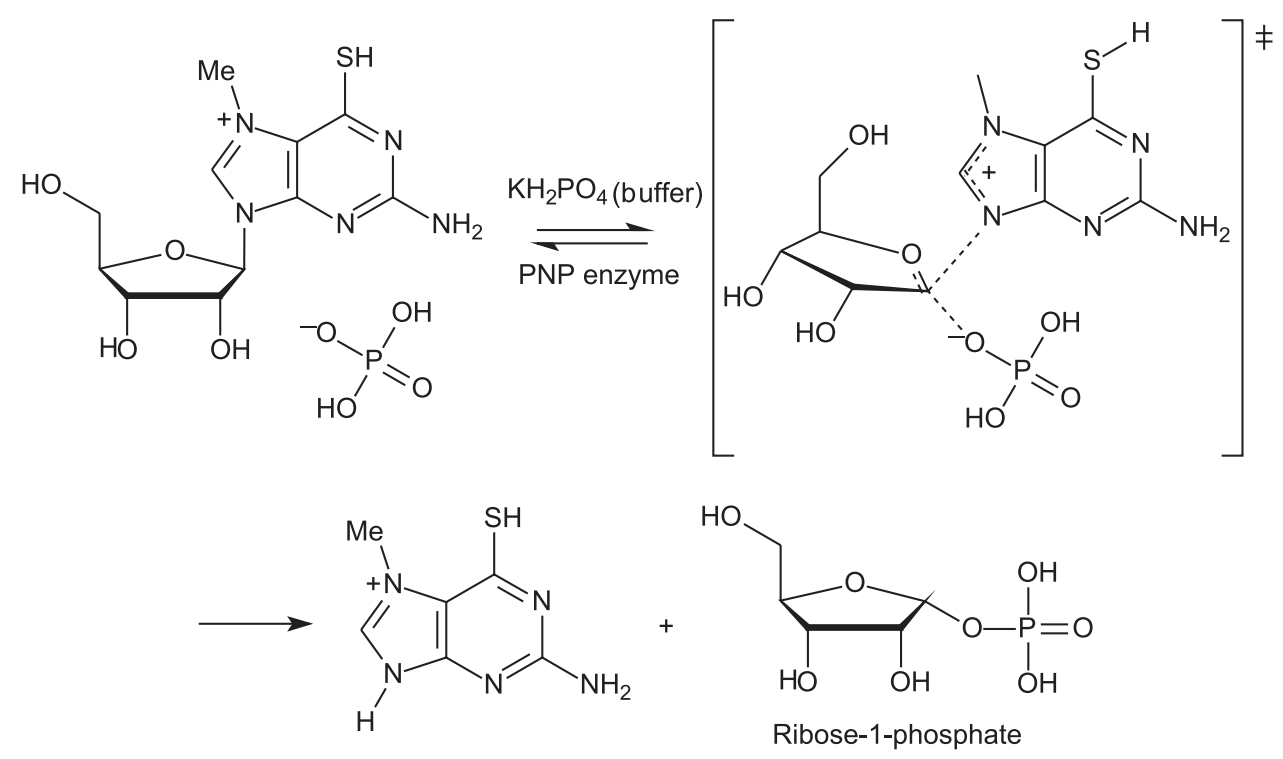

Scheme 3. Proposed transition state blueprint for the phosphorolysis reaction of MESG 1.

The enzymatic promoted phosphorolysis reaction of $\mathbf{1}$ catalyzed by PNP may proceed through a transition state blueprint (Scheme 3), as previously proposed for inosine, the natural enzyme substrate, and recently reviewed. ${ }^{20}$

It is possible to initiate a discussion whether the mechanism may proceed through an $\mathrm{S}_{\mathrm{N}} 1$ or $\mathrm{S}_{\mathrm{N}} 2$ mechanism for PNP substrates. ${ }^{21-23} \mathrm{~A}$ total inversion of the chiral centre in the ribose-1-phosphate product indicates an $\mathrm{S}_{\mathrm{N}} 2$ mechanism; however, many studies conducted by Schramm's group indicate an $\mathrm{S}_{\mathrm{N}} 1$ mechanism. Based on our experience studying reaction mechanisms using mass spectrometry ${ }^{24}$ (including enzymatic biotransformation ${ }^{12}$ study), we decided to perform a test to gain insight into the mechanism of the phosphorolysis reaction of $\mathbf{1}$ promoted by PNP enzyme by monitoring the chemically mimicked reaction by electrospray ionization mass spectrometry (ESI). When mixing inorganic phosphate and MESG (water solution), on-line electron ionization (tandem) mass spectrometry monitoring the high resolution ESI(+)-MS was recorded after $10 \mathrm{~min}$ of vortex stirring (Figure 2).

We can observe in Figure 2 (A) the presence of $1(\mathrm{~m} / \mathrm{z}$ $314.0931)$, the free base $(\mathrm{m} / \mathrm{z} 182)$, the protonated ribose-1phosphate and also a signal at $m / z$ 133.0507. This signal was attributed to an oxonium cation derived from ribose moiety of $\mathbf{1}$, which is formed when mixing the reagents. Owing to the very low intensity of the signal, an ESI(+)-MSMS could not be recorded, but the high resolution mass points firmly to the online interception of the species. The ESI(+)-MSMS characterization of $\mathbf{1}$ (Figure 2, B) guarantees that the species is derived from the synthesized substrate. The mild transfer to the gas phase using ESI techniques indicates that
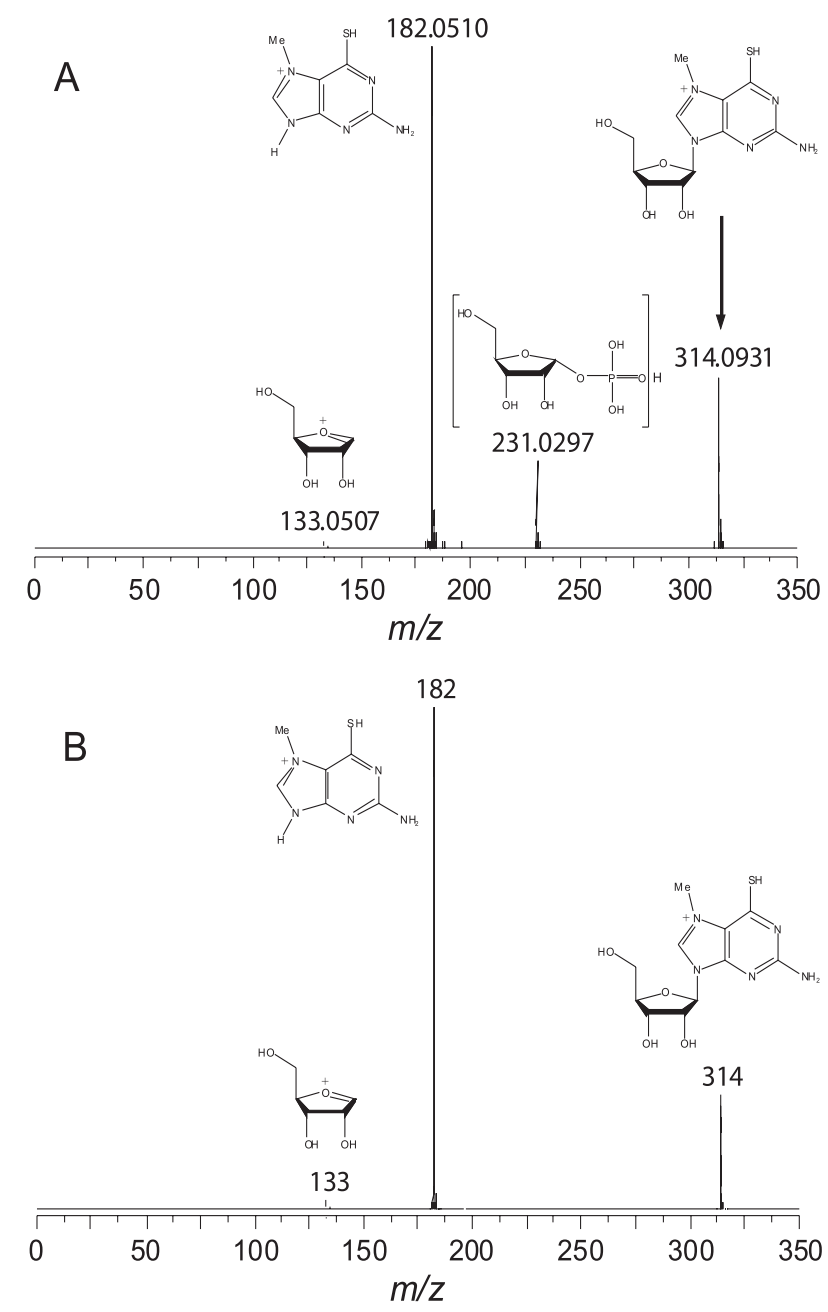

Figure 2. (A) High resolution ESI(+)-MS of MESG and inorganic phosphate in water. (B) ESI(+)-MSMS of pure MESG $(\mathrm{m} / z, 314)$. 
in fact, the mechanism of the phosphorolysis reaction may proceed through a $\mathrm{S}_{\mathrm{N}} 1$ pathway, as suggested by others. ${ }^{21}$

According to the calculation results (supplementary information, Table $\mathrm{S} 1$ ), the basic $\mathrm{pH}$ tautomers are energetically more stable than the acidic $\mathrm{pH}$ tautomers. Taking the isolated molecules of reactants and products as reference, the calculated activation energies, regardless of the isomers or level of calculation, would be negative. Taking into account the molecules of reactants and products as being near to one another, which is more representative of the condensed phase, the effective activation energies would be approximately $100 \mathrm{~kJ} \mathrm{~mol}^{-1}$ in the RHF 3-21G level, and larger than $65 \mathrm{~kJ} \mathrm{~mol}^{-1}$ in the highest calculation level (RHF 6-31G**), which indicate that the $\mathrm{S}_{\mathrm{N}} 2$ mechanism, under these conditions, would be highly improbable. Indeed, it can be energetically discarded. The results clearly indicate that the $\mathrm{S}_{\mathrm{N}} 1$ pathway would be preferred. In fact, in the enzymatic environment, the idea of an $\mathrm{S}_{\mathrm{N}} 1$ mechanism is fairly plausible (Scheme 4 , see supplementary information for the colour version).

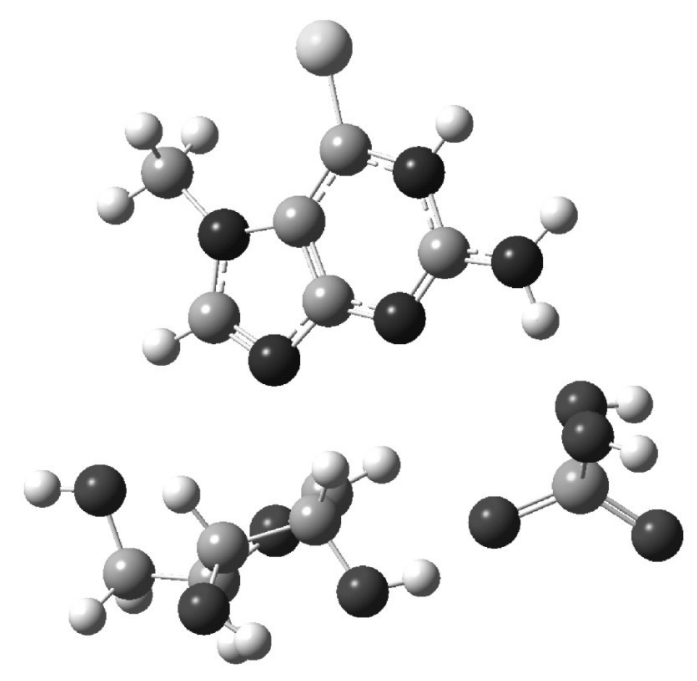

Scheme 4. Calculated blueprint transition state for the phosphorolysis reaction catalyzed by PNP enzyme. Note that it is based on an $\mathrm{S}_{\mathrm{N}} 1$ mechanism.

One further test was performed using freshly synthesized compound 1. An enzymatic assay promoted by human PNP accomplished the phosphorolysis reaction (Figure 3). When we used a Mycobacterium tuberculosis PNP source, similar results were obtained.

It is clear from the data displayed in Figure 3 that freshly synthesized compound $\mathbf{1}$ has a very good efficiency to be used as a biosensor for inorganic phosphate measurements by human PNP-catalyzed phosphorylase reaction. Reproducible data can be obtained after storing compound $\mathbf{1}$ at very low temperatures $\left(-80^{\circ} \mathrm{C}\right)$ even after months of storage.

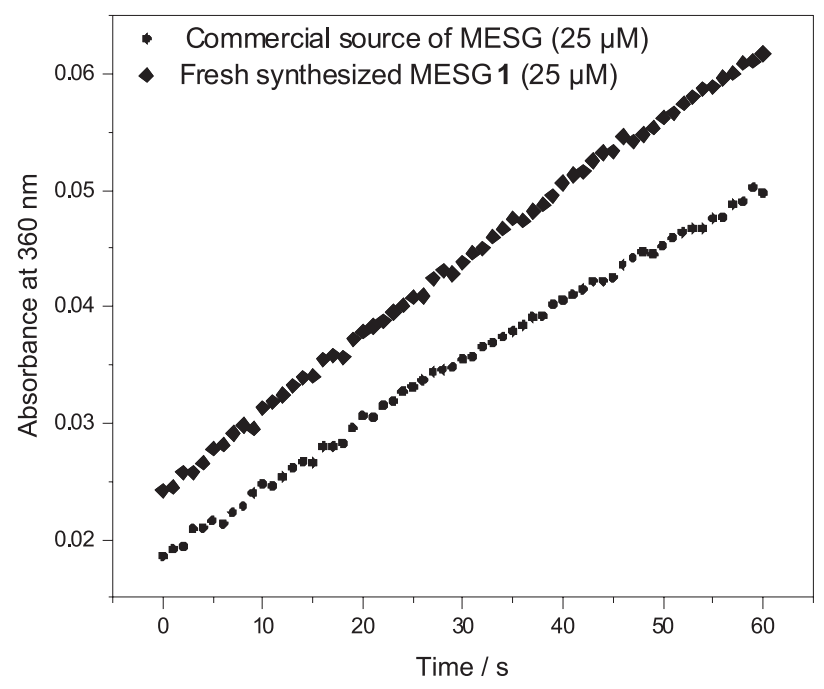

Figure 3. Changes in absorbance at $360 \mathrm{~nm}$ due to the phosphorylasecatalyzed reaction of $\left.\mathbf{1}(200 \mu \mathrm{mol} \mathrm{L})^{-1}\right)$ with inorganic phosphate (from a stock solution of $\mathrm{KH}_{2} \mathrm{PO}_{4} 50 \mathrm{mmol} \mathrm{L}^{-1}$ ) promoted by human PNP in Tris- $\mathrm{HCl}$ buffer at $\mathrm{pH} 7.6$.

\section{Conclusions}

In summary, we have described an improved and simple synthesis of MESG and its complete characterization. We have also demonstrated the value of mass spectrometry in furnishing mechanistic insights into important catalytic phosphorolysis reactions such as that of MESG. Our findings, supported by calculations, point to an $\mathrm{S}_{\mathrm{N}} 1$ mechanism instead of an $\mathrm{S}_{\mathrm{N}} 2$. Moreover, an improved synthesis and full characterization of MESG has been described.

\section{Acknowledgments}

Thanks are due to FAPERGS, PETROBRAS, CAPES and $\mathrm{CNPq}$ for financial support.

\section{Supplementary Information}

Supplementary material including Tables and NMR spectra is available free of charge at http://jbcs.sbq.org.br, as pdf file.

\section{References}

1. Webb, M. R.; Proc. Natl. Acad. Sci. U. S. A. 1992, 89, 4884.

2. Cheng, J. M.; Farutin, V.; Wu, Z. J.; Jacob-Mosier, G.; Riley, B.; Hakimi, R.; Cordes, E. H.; Bioorg. Chem. 1999, 27, 307.

3. Kulikowska, E.; Bzowska, A.; Wierzchowski, J.; Shugar, D.; Biochim. Biophys. Acta 1986, 874, 355.

4. Rieger, C. E.; Lee, J.; Turnbull, J. L.; Anal. Biochem. 1997, 246, 86. 
5. Montgomery, J. A.; Expert Opin. Invest. Drugs 1994, 3, 1303.

6. Markert, M. L.; Immunodefic. Rev. 1991, 3, 45.

7. Giblett, E. R.; Ammann, A. J.; Sandman, R.; Wara, D. W.; Diamond, L. K.; Lancet 1975, 1, 1010.

8. Stoop, J. W.; Zegers, B. J. M.; Hendrickx, G. F. M.; Siegenbeekvanheukelom, L. H.; Staal, G. E. J.; Debree, P. K.; Wadman, S. K.; Ballieux, R. E.; N. Engl. J. Med. 1977, 296, 651.

9. Neto, B. A. D.; Lapis, A. A. M.; Mancilha, F. S.; Vasconcelos, I. B.; Thum, C.; Basso, L. A.; Santos, D. S.; Dupont, J.; Org. Lett. 2007, 9, 4001.

10. Neto, B. A. D.; Lopes, A. S.; Wust, M.; Costa, V. E. U.; Ebeling, G.; Dupont, J.; Tetrahedron Lett. 2005, 46, 6843.

11. Pinto, A. C.; Lapis, A. A. M.; da Silva, B. V.; Bastos, R. S.; Dupont, J.; Neto, B. A. D.; Tetrahedron Lett. 2008, 49, 5639.

12. Czekster, C. M.; Lapis, A. A. M.; Souza, G.; Eberlin, M. N.; Basso, L. A.; Santos, D. S.; Dupont, J.; Neto, B. A. D.; Tetrahedron Lett. 2008, 49, 5914.

13. Pilli, R. A.; Robello, L. G.; Camilo, N. S.; Dupont, J.; Lapis, A. A. M.; Neto, B. A. D.; Tetrahedron Lett. 2006, 47, 1669.

14. Broom, A. D.; Milne, G. H.; J. Heterocycl. Chem. 1975, 12, 171.

15. Silva, R. G.; Pereira, J. H.; Canduri, F.; de Azevedo, W. F.; Basso, L. A.; Santos, D. S.; Arch. Biochem. Biophys. 2005, $442,49$.
16. Spencer, J.; Gaffen, J.; Griffin, E.; Harper, E. A.; Linney, I. D.; McDonald, L. M.; Roberts, S. P.; Shaxted, M. E.; Adatia, T.; Bashall, A.; Bioorg. Med. Chem. 2008, 16, 2974.

17. Spencer, J.; Rathnam, R. P.; Patel, H.; Anjum, N.; Tetrahedron 2008, 64, 10195.

18. Russowsky, D.; Neto, B. A. D.; Tetrahedron Lett. 2004, 45, 1437.

19. Russowsky, D.; Neto, B. A. D.; Tetrahedron Lett. 2003, 44, 2923.

20. Basso, L. A.; da Silva, L. H. P.; Fett-Neto, A. G.; Junior, W. F. D.; Moreira, I. D.; Palma, M. S.; Calixto, J. B.; Astolfi, S.; dos Santos, R. R.; Soares, M. B. P.; Santos, D. S.; Mem. Inst. Oswaldo Cruz, 2005, 100, 575.

21. Kline, P. C.; Schramm, V. L.; Biochemistry 1995, 34, 1153.

22. Kline, P. C.; Schramm, V. L.; Biochemistry 1993, 32, 13212.

23. Kline, P. C.; Schramm, V. L.; Biochemistry 1992, 31, 5964.

24. Santos, L. S.; Neto, B. A. D.; Consorti, C. S.; Pavam, C. H.; Almeida, W. P.; Coelho, F.; Dupont, J.; Eberlin, M. N.; J. Phys. Org. Chem. 2006, 19, 731.

Received: March 4, 2009 Web Release Date: October 30, 2009 


\section{Synthesis and Enzymatic Evaluation of the Guanosine Analogue 2-Amino-6-mercapto-7- methylpurine Ribonucleoside (MESG). Insights into the Phosphorolysis Reaction Mechanism based on the Blueprint Transition State: $S_{N} 1$ or $S_{N} 2$ ?}

\section{Brenno A. D. Neto, ${ }^{*, a}$ Alexandre A. M. Lapis, ${ }^{b}$ Paulo A. Netz, ${ }^{c}$ John Spencer, ${ }^{d}$ Silvio L. P. Dias, ${ }^{c}$ Silvia M. Tamborim, ${ }^{c}$ Luiz A. Basso, ${ }^{e}$ Diógenes S. Santos ${ }^{e}$ and Jaïrton Dupont ${ }^{*, c}$}

${ }^{a}$ Laboratory of Medicinal and Technological Chemistry, University of Brasilia (IQ-UnB), 72919-970 Brasilia-DF, Brazil

${ }^{b}$ Universidade Federal do Pampa, Unipampa, 96412-420 Bagé-RS, Brazil

${ }^{c}$ Laboratory of Molecular Catalysis-Institute of Chemistry -UFRGS, Av. Bento Gonçalves, 9500, 91501-970 Porto Alegre-RS, Brazil

${ }^{d}$ School of Science, University of Greenwich at Medway, Chatham Maritime, ME4 4TB, UK

${ }^{e}$ Centro de Pesquisas em Biologia Molecular e Funcional, Tecnopuc, PUC-RS, Brazil

Table S1. MESG calculations energies

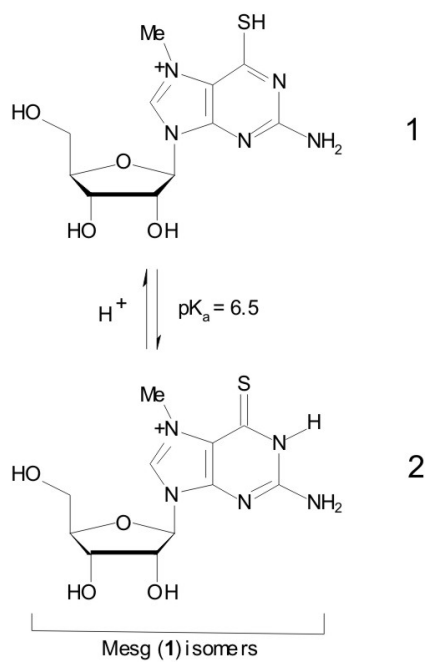

\begin{tabular}{|l|l|l|l|}
\hline & Structure & $321 \mathrm{G}$ & $631 \mathrm{G}^{* *}$ \\
\hline 1 & MESG1 & -1387.3591 & -1394.9106 \\
\hline 2 & MESG2 & -1387.3892 & -1394.9176 \\
\hline 3 & PHOSPHATE $\left(\mathrm{H}_{2} \mathrm{PO}_{4}^{-}\right)$ & -637.9914 & -641.4856 \\
\hline $4(1+3)$ & MESG1 + PHOSPHATE & -2025.3505 & -2036.3962 \\
\hline $5(2+3)$ & MESG2 + PHOSPHATE & -2025.3806 & -2036.4032 \\
\hline 6 & REACTANTS 1 & -2025.5167 & -2036.5672 \\
\hline 7 & REACTANTS 2 & -2025.5711 & -2036.5594 \\
\hline 8 & TRANSITION STATE 1 & -2025.4802 & \\
\hline 9 & TRANSITION STATE 2 & -2025.5258 & -2036.5340 \\
\hline
\end{tabular}

\begin{tabular}{|c|c|c|c|}
\hline & Structure & $321 \mathrm{G}$ & $631 \mathrm{G} * *$ \\
\hline 10 & PRODUCTS 1 & -2025.5386 & -2036.5670 \\
\hline 11 & PRODUCTS 2 & -2025.5751 & -2036.5734 \\
\hline $12(14+16)$ & FREE BASE $1+$ RIB-1-P & -2025.5147 & -2036.5494 \\
\hline $13(15+16)$ & FREE BASE 2 + RIB-1-P & -2025.5514 & -2036.5620 \\
\hline 14 & FREE BASE $1(\mathrm{ch}=0)$ & -896.2612 & -901.0708 \\
\hline 15 & FREE BASE $2(\mathrm{ch}=0)$ & -896.2979 & -901.0834 \\
\hline 16 & RIBOSE-1-PHOSPHATE & -1129.2535 & -1135.4786 \\
\hline $17(10-6)$ & $\Delta \mathrm{H}_{\mathrm{R} 1}(\mathrm{P}-\mathrm{R})$ & \begin{tabular}{|l|}
-0.0219 \\
$-57.50 \mathrm{kJmol}^{-1}$
\end{tabular} & $\begin{array}{l}+0.0002 \\
0.52 \mathrm{kJmol}^{-1}\end{array}$ \\
\hline $18(11-7)$ & $\Delta \mathrm{H}_{\mathrm{R} 2}(\mathrm{P}-\mathrm{R})$ & $\begin{array}{l}-0.004 \\
-10.50 \mathrm{kJmol}^{-1}\end{array}$ & \begin{tabular}{|l}
-0.014 \\
$-36.76 \mathrm{kJmol}^{-1}$
\end{tabular} \\
\hline 19 (12-4) & $\Delta \mathrm{H}_{\mathrm{R} 1}(\mathrm{P}-\mathrm{R})$ (isolated) & $\begin{array}{l}-0.1642 \\
-431.1 \mathrm{kJmol}^{-1}\end{array}$ & $\begin{array}{l}-0.1532 \\
-402.2 \mathrm{kJmol}^{-1}\end{array}$ \\
\hline $20(13-5)$ & $\Delta \mathrm{H}_{\mathrm{R} 2}(\mathrm{P}-\mathrm{R})$ (isolated) & \begin{tabular}{|l|}
-0.1708 \\
$-448.4 \mathrm{kJmol}^{-1}$
\end{tabular} & \begin{tabular}{|l}
0.1588 \\
$-416.9 \mathrm{kJmol}^{-1}$
\end{tabular} \\
\hline $21(8-4)$ & $\mathrm{EA}_{1}$ & \begin{tabular}{|l}
-0.1297 \\
$-340.0 \mathrm{kJmol}^{-1}$
\end{tabular} & - \\
\hline $22(9-5)$ & $\mathrm{EA}_{2}$ & \begin{tabular}{|l}
-0.1452 \\
$-381.2 \mathrm{kJmol}^{-1}$ \\
\end{tabular} & \begin{tabular}{|l}
0.1308 \\
$-343.4 \mathrm{kJmol}^{-1}$
\end{tabular} \\
\hline $23(8-6)$ & $\mathrm{EA}_{1}^{\prime}$ & $\begin{array}{l}+0.0365 \\
+95.83 \mathrm{kJmol}^{-1}\end{array}$ & - \\
\hline $24(9-7)$ & $\mathrm{EA}_{2}^{\prime}$ & $\begin{array}{l}+0.0453 \\
+118.9 \mathrm{kJmol}^{-1}\end{array}$ & $\begin{array}{l}+0.0254 \\
+66.69 \mathrm{kJmol}^{-1}\end{array}$ \\
\hline $25 \quad(1-2)$ & $\Delta \mathrm{H}_{\text {interconversion, isol }}(\mathrm{R} 1-\mathrm{R} 2)$ & $\begin{array}{l}+0.0301 \\
+79.0 \mathrm{kJmol}^{-1}\end{array}$ & $\begin{array}{l}+0.007 \\
+18.4 \mathrm{kJmol}^{-1}\end{array}$ \\
\hline $26(14-15)$ & $\Delta \mathrm{H}_{\text {interconversion, isol }}(\mathrm{P} 1-\mathrm{P} 2)$ & $\begin{array}{l}+0.0367 \\
+96.4 \mathrm{kJmol}^{-1}\end{array}$ & $\begin{array}{l}+0.0126 \\
+33.1 \mathrm{kJmol}^{-1}\end{array}$ \\
\hline 27 & FREE BASE $1(\mathrm{ch}=+1)$ & -896.6645 & -901.4640 \\
\hline 28 & FREE BASE $2(\mathrm{ch}=+1)$ & -896.6966 & -901.4724 \\
\hline
\end{tabular}

\footnotetext{
*e-mail: brenno.ipi@gmail.com and jairton.dupont@ufrgs.br
} 


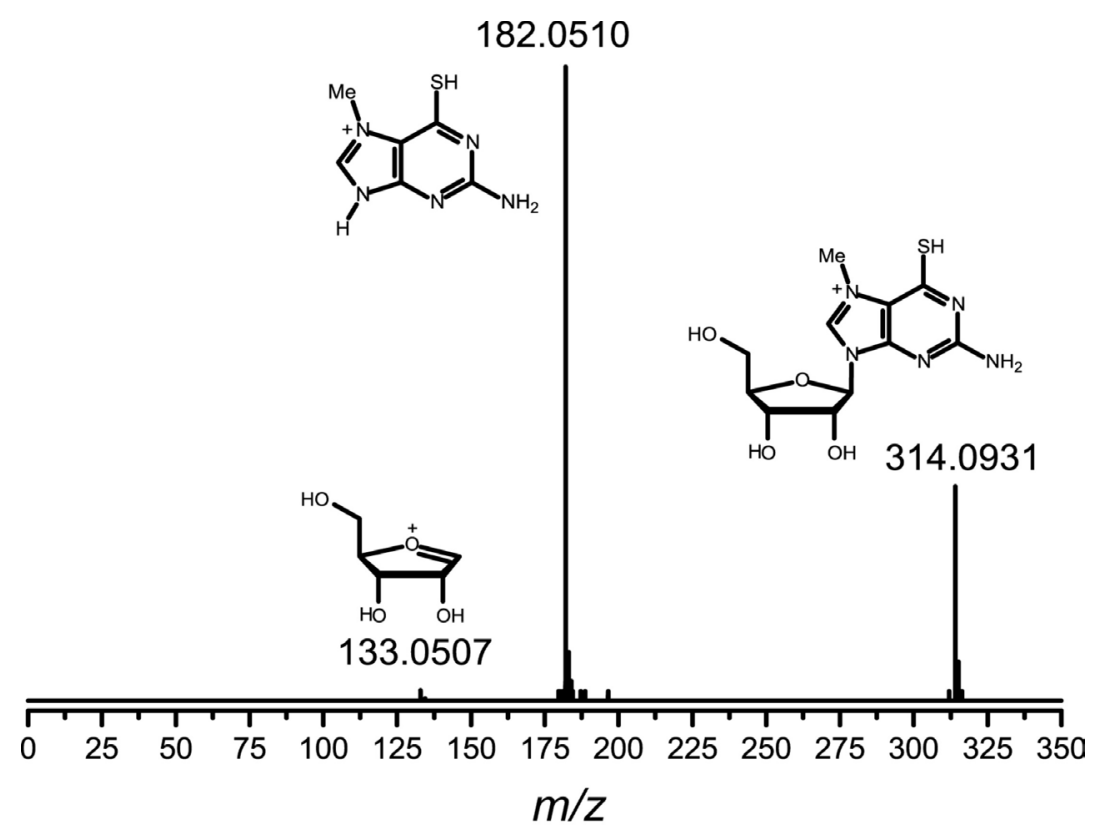

Figure S1. High resolution ESI(+)MSMS

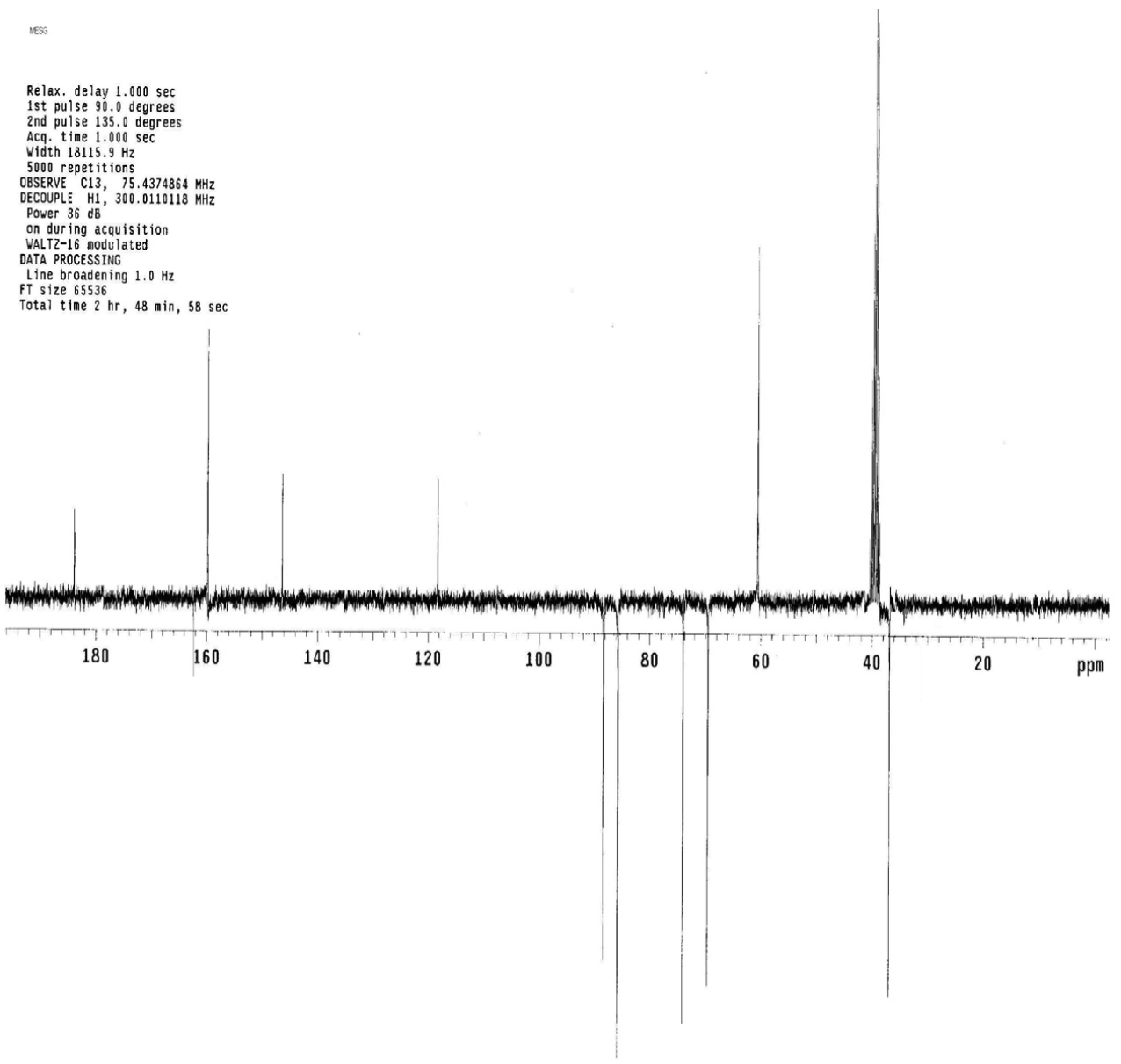

Figure S2. ${ }^{13} \mathrm{C}$ NMR (APT) (DMSO-d $\left.{ }_{6}\right)$ 


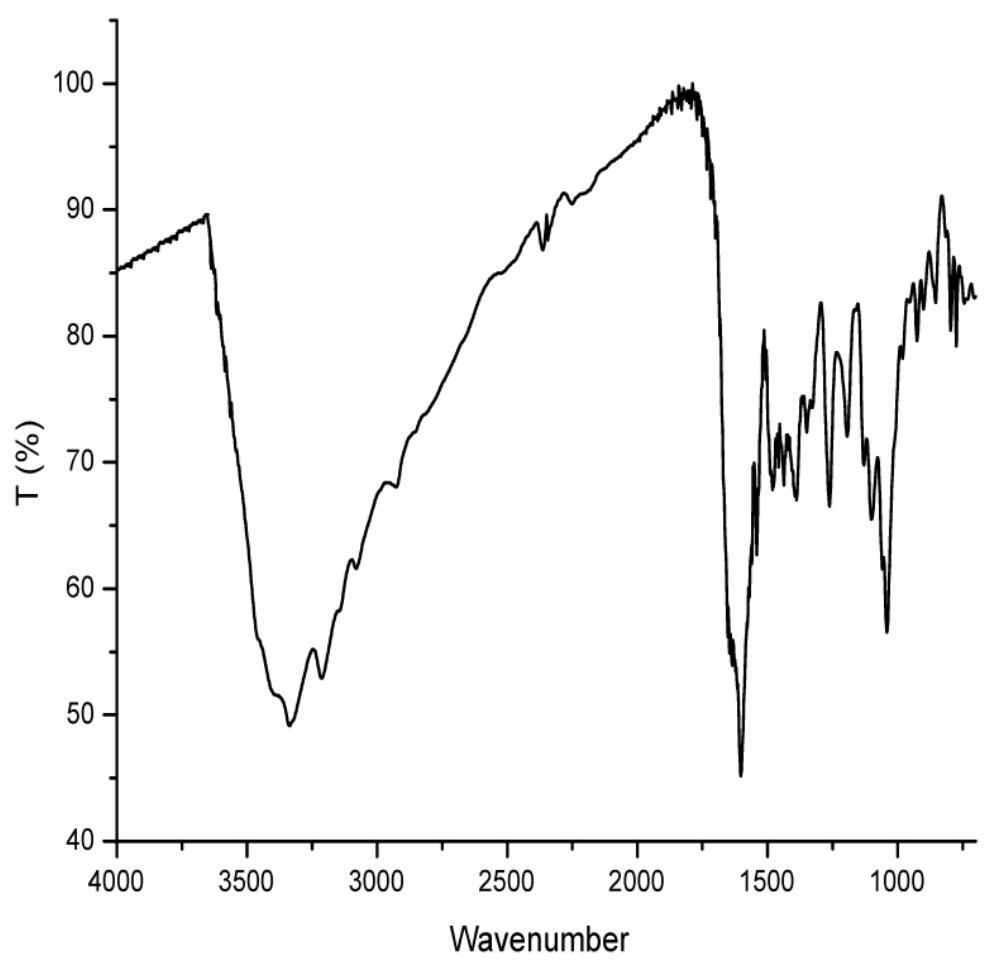

Figure S3. FTIR (KBr, $\left.v_{\max } / \mathrm{cm}^{-1}\right)$

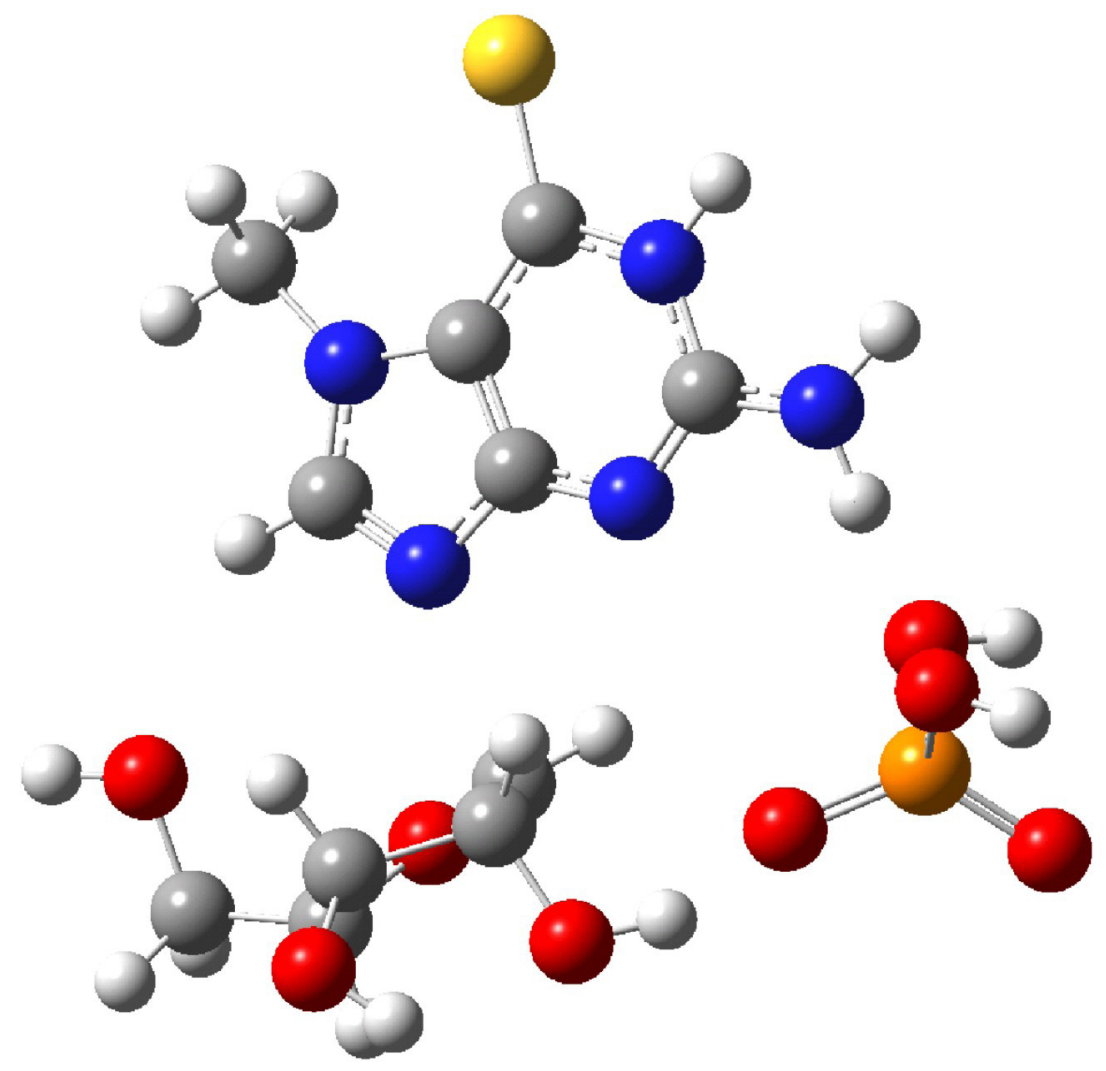

Figure S4. Calculated transition state 